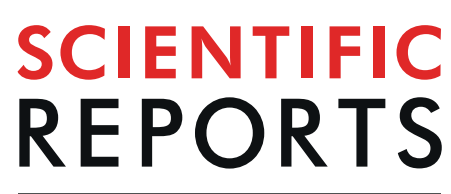

natureresearch

\title{
Green solvents and Ultrasound- Assisted Extraction of bioactive orange (Citrus sinensis) peel compounds
}

\begin{abstract}
Abigail Montero-Calderon (1D, Clara Cortes, Ana Zulueta, Ana Frigola \& Maria J. Esteve (i])
Byproducts such as orange peel have potential uses because of their bioactive compounds, which are important for their potential to reduce the risk factors of diseases caused by aging. The lack of effective techniques and the high levels of pollution produced by the conventional extraction of bioactive compounds using organic solvents have highlighted the need to enhance the 'green chemistry' trend. This study evaluates the use of ultrasound to extract bioactive compounds from orange peel. The antioxidant capacity, phenolic content, ascorbic acid, total carotenoids, and HPLC profile of phenolic compounds from orange peel extracts were obtained by a physicochemical evaluation. The results demonstrate that the optimal conditions for the ultrasound-assisted extraction of bioactive orange peel compounds were a power of $400 \mathrm{~W}$, a time of $30 \mathrm{~min}$, and $50 \%$ ethanol in water. These conditions were used to obtain a total carotenoid concentration of $0.63 \mathrm{mg}$ ß-carotene $/ 100 \mathrm{~g}$, vitamin C concentration of $53.78 \mathrm{mg} \mathrm{AA} / 100 \mathrm{~g}$, phenolic concentration of $105.96 \mathrm{mg} \mathrm{GAE} / 100 \mathrm{~g}$, and antioxidant capacity of $\mathrm{ORAC}=27.08 \mathrm{mM}$ TE and TEAC $=3.97 \mathrm{mMTE}$. The major phenolic compound identified in all orange peel extracts was hesperidin, with a maximum concentration of $113.03 \pm 0.08 \mathrm{mg} / 100 \mathrm{~g}$.
\end{abstract}

The current food trends around the world are aligned with the healthy and sustainable consumption of natural products, such as fruits and vegetables. An example of this is the Slow Food movement, which aims to counteract the spread of fast food ${ }^{1}$. The World Health Organization (WHO) recommends a minimum intake of $600 \mathrm{~g} / \mathrm{per}-$ son/day of fruits and vegetables because their vitamins, carotenoids, and polyphenols can prevent ischemic heart disease, cerebrovascular disease, and cancer of the stomach, colon, esophagus, and lung ${ }^{2,3}$.

In this context, orange has important nutritional components, such as amino acids, carbohydrates, fiber, proteins, vitamins, and minerals ${ }^{4}$. This citrus is historically the most consumed fruit $(77.3 \mathrm{~g} /$ person/day) and has been experiencing a favorable evolution of consumption since $2000^{5}$. In 2013, the total orange production in Spain reached 3.536.745 tonnes ${ }^{6}$.

As food consumption has increased, its waste has increased, which has negative implications for natural resources conservation ${ }^{7}$. Food waste is a solid or liquid substance that is deliberately or unintentionally discarded during the processing, preparation, storage, handling, or selling of food. Organic waste, such as fruit peel, is also considered food waste ${ }^{8}$. In 2013, the European Union set the objective of reducing 50\% of its food waste by $2020^{9}$. In 2015, the United States proclaimed the national goal of reducing half the food waste and loss of food by $2030^{7}$.

As reported by Park et al. ${ }^{10}$ reported that compounds extracted from fruit residues can be used in functional and nutraceutical foods because of their antioxidant content. Citrus residues are the seeds, remnants of the pulp after squeezing the juice, and peel, which comprises the albedo and flavedo ${ }^{11}$. Vitamin $\mathrm{C}$ and $\mathrm{B}$-carotene are abundant compounds in the pulp and peel of citrus ${ }^{3}$; flavones, flavanones, chalcones, and dihydrochalcones are flavonoids characteristic of the genus Citrus ${ }^{12}$

The lack of effective techniques for processing citrus residues to obtain a quality raw material suitable for new products is one of the fundamental reasons that this matrix is not leveraged in the industry. Similarly, the low efficiency and environmental pollution produced by the organic solvents used in conventional extraction have highlighted the need to enhance the trend known as 'green chemistry' and develop methods that produce less pollution and achieve the high-performance extraction of bioactive compounds in a short time and at low cost. 
The most frequently used techniques in clean extraction are ultrasound-assisted extraction (UAE), microwaves, and extraction with supercritical fluids ${ }^{12}$.

UAE is based on the application of ultrasounds $(20-100 \mathrm{kHz})$ that cause the implosion of the cavitation bubbles of cells on which the acoustic waves are propagated, leading to the disruption of cell membranes. This action facilitates the penetration of solvent into the cells, thereby improving mass transfer and releasing bioactive compounds. The performance of phenolic compound extraction using UAE has been verified ${ }^{13}$, but the solvents used in the verification produce serious environmental pollution. Therefore, it is necessary to continue studying the optimization of bioactive compound extraction using 'green solvents' such as ethanol and water. To this end, the aim of this study is to obtain bioactive compounds from orange peel with an extraction method that combines $\mathrm{UAE}$ and environmentally friendly solvents.

\section{Results and Discussion}

The effect of ultrasound extraction on physicochemical properties. Several parameters $(\mathrm{pH}$, degrees Brix, conductivity, and color) of the extracts were determined. All orange extracts had an acidity $\mathrm{pH}$ between $4.91 \pm 0.00$ and $5.97 \pm 0.01$, while Irkin et al. ${ }^{14}$ reported a $\mathrm{pH}$ of $6.62 \pm 2.2$ for orange peel extracts in their investigation.

Degrees Brix increased as ultrasonic power, extraction time, and ethanol concentration increased $(17.05 \pm 0.07$ ${ }^{\circ} \mathrm{Bx} ; 400 \mathrm{~W}, 30 \mathrm{~min}$, and $50 \%$ ethanol). Legua et al. ${ }^{15}$ obtained values from 12.2 to $14.2^{\circ} \mathrm{Bx}$ for tangerine juice and expressed that the determination of ${ }^{\circ} \mathrm{Bx}$ is related to the soluble solids content in a solution, especially sugars. The increase in ${ }^{\circ} \mathrm{Bx}$ correlates with the intensity of the ultrasonic treatment applied, which means an increase in the breakage of plant cells and the diffusion of the content into the extraction liquid. In the same way, the highest conductivity value obtained was $0.45 \pm 0.14 \mathrm{mS} / \mathrm{cm}$ with $400 \mathrm{~W}, 30 \mathrm{~min}$, and $0 \%$ ethanol. The conductivity represents the electrolytic content of the extracts of orange peel, therefore, it shows the exit from inside the plant cells.

The colors of the extracts ranged between brown and yellow and are represented by the following values: $\mathrm{L}^{*}$ : $5.75 \pm 0.03$ to $40.24 \pm 0.02 ; \mathrm{a}^{*}:-1.15 \pm 0.01$ to $4.15 \pm 0.05$; and $\mathrm{b}^{*}: 2.47 \pm 0.01$ to $18.63 \pm 0.03$. The main extraction of pigments $\left(\Delta \mathrm{E}^{*}\right)$ was obtained for the high value of ultrasound power $(400 \mathrm{~W})$. A similar result was reported for the characterization of commercial orange nectar $\left(\mathrm{L}^{*} 39.5 \pm 3.00 ; \mathrm{a}^{*}-3.72 \pm 0.90 ; \mathrm{b} * 16.4 \pm 4.80\right)$ by Alvarez et $a l .{ }^{16}$, who emphasized the importance of color for the acceptability of a product because it is the first visible quality.

Determination of antioxidant capacity. ORAC analysis obtained values between $4.35 \pm 0.39(100 \mathrm{~W}$, $5 \mathrm{~min}, 0 \%$ ethanol) and $29.23 \pm 2.38 \mathrm{mM} \mathrm{TE}(400 \mathrm{~W}, 5 \mathrm{~min}, 50 \%$ ethanol). These results are higher than those obtained by Park et al. ${ }^{10}$ of $0.006 \mathrm{mM}$ TE for orange peel extracts obtained through conventional extraction using acetone.

For TEAC, the values were from $0.89 \pm 0.07 \mathrm{mM}$ TE $(100 \mathrm{~W}, 5 \mathrm{~min}, 0 \%$ ethanol) to $3.97 \pm 0.15 \mathrm{mM} \mathrm{TE}(400 \mathrm{~W}$, $30 \mathrm{~min}, 50 \%$ ethanol), which are higher than the value obtained by Mhiri et al..$^{17}$ for orange peel extracts using UAE ( $0.003 \mathrm{mM} \mathrm{TE} ; 125 \mathrm{~W}, 30 \mathrm{~min}, 80 \%$ ethanol). The increase in antioxidant capacity is due to an increase in compounds with antioxidant capacity, because the cavitation phenomena cause the breakage of plant walls.

ANOVA results show that ultrasound power $(\mathrm{P})$, ultrasound irradiation time $(\mathrm{T})$, and the concentration of ethanol in water $(E)$ had a significant effect $(p<0.05)$ on the antioxidant capacity of orange peel extracts. The experimental data are in accordance with the second-order polynomial equations expressed as follows:

$$
\begin{aligned}
\text { ORAC }(\mathrm{mM} \mathrm{TE})= & 0.080 * \mathrm{P}+0.485 * \mathrm{~T}+0.063 * \mathrm{E} \\
& -0.0001 * \mathrm{P}^{2}-0.001 * \mathrm{P} * \mathrm{~T}+0.001 \\
& * \mathrm{P} * \mathrm{E}+0.005 * \mathrm{~T} * \mathrm{E}-5.286
\end{aligned}
$$

$\left(\mathrm{R}^{2}=87.03, \mathrm{p}<0.05\right.$, standard error $\left.=2.85\right)$

$$
\begin{aligned}
\text { TEAC }(m M T E)= & 1.774-0.012 * P+0.022 * T \\
& +0.039 * E+2.5 * 10^{-5} * P^{2}+0.0001 * \\
& P * T-0.001 * E^{2}
\end{aligned}
$$

$\left(\mathrm{R}^{2}=75.68, \mathrm{p}<0.05\right.$, standard error $\left.=0.38\right)$

where $\mathrm{R}^{2}$ indicates that the models predict $87.03 \%$ and $75.68 \%$ of the results obtained by ORAC and TEAC, respectively.

Vitamin C. The minimum and maximum ascorbic acid values obtained were $8.89 \pm 1.54$ and $93.33 \pm 2.67 \mathrm{mg}$ $\mathrm{AA} / 100 \mathrm{~g}$; these results are in some agreement with the concentration of $99 \mathrm{mg} \mathrm{AA} / 100 \mathrm{~g}$ obtained by Cano and Bermejo $^{18}$ from orange albedo extract (C. sinensis L. cv. Navelina). ANOVA results show that ultrasound power $(\mathrm{P})$, ultrasound irradiation time $(\mathrm{T})$, the power-time interaction $(\mathrm{P} * \mathrm{~T})$, and time-ethanol interaction $(\mathrm{T} * \mathrm{E})$ are the main factors $(\mathrm{p}<0.05)$ that affect ascorbic acid extraction from orange peel according to the following model:

$$
A A\left(\frac{m g}{100 g}\right)=-10.632-0.005 * P+1.879 * T+0.004 * P * T-0.029 * T * E
$$

$\left(\mathrm{R}^{2}=70.45, \mathrm{p}<0.05\right.$, standard error $\left.=13.67\right)$

Total carotenoids. The high carotenoid value obtained was $0.63 \pm 0.01 \mathrm{mg} ß$-carotene $/ 100 \mathrm{~g}$; in some experiments, it was not detected (ND). The results for the total carotenoid content of orange peel are usually variable; in a study by Fidrianny et al. ${ }^{19}$, the carotenoids reached $21 \mathrm{mg}$ B-carotene $/ 100 \mathrm{~g}$ from the extraction of orange 


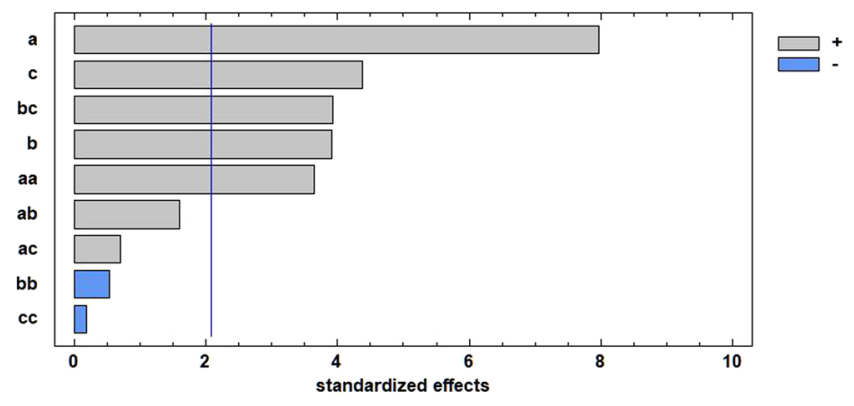

Figure 1. Pareto diagram for the extraction of TSP from orange peel. $a=$ ultrasound power $(\mathrm{W}), \mathrm{b}=\mathrm{ultrasound}$ irradiation time (min), $\mathrm{c}=$ concentration of ethanol in water $(\%)$.

peel with $100 \%$ ethanol. The ANOVA results show that only the extraction time and percentage of ethanol have a statistically significant influence $(\mathrm{p}<0.05)$ on carotenoid extraction. The contribution of the experimental factors to CT values are represented by the following equation:

$$
C T\left(\frac{m g}{100 g}\right)=0.143-0.01 * T+0.004 * E
$$

$\left(\mathrm{R}^{2}=53.60, \mathrm{p}<0.05\right.$, standard error $\left.=0.11\right)$

Total soluble phenols. TSP content ranged from $16.01 \pm 1.59$ to $105.96 \pm 1.92 \mathrm{mg}$ GAE/100 g. There are diverse results because of the variety of citrus, extraction conditions, and solvents. Kour et al. ${ }^{11}$ determined a phenolic content of $17.1 \pm 1.04 \mathrm{mg}$ GAE/g in mandarin residues, Park et al. ${ }^{10}$ found $1.39 \mathrm{mg}$ GAE/100 g in orange peel, Irkin et al. ${ }^{14}$ obtained $1108 \mathrm{mg} \mathrm{GAE} / 100 \mathrm{~g}$ from orange peel, and Fidrianny et al.$^{19}$ determined that the average content in the peel of three varieties of orange was $9.49 \mathrm{mg} \mathrm{GAE} / 100 \mathrm{~g}$ with conventional extraction using ethanol.

Linear effects, quadratic effects, and interactions between experimental factors were statistically significant for the extraction of TSP from orange peel (Fig. 1). The horizontal bars represent the positive and negative effects of the experimental factors on the response variable, while the vertical line indicates the significance of these effects at a $95 \%$ confidence level.

There are five statistically significant effects in UAE of phenols from orange peel: the linear effect of ultrasound power $(\mathrm{P})$, the linear effect of ethanol percentage $(\mathrm{E})$, the quadratic effect of the time-ethanol interaction $(\mathrm{T} * \mathrm{E})$, the linear effect of extraction time $(\mathrm{T})$, and the quadratic effect of ultrasound power $\left(\mathrm{P}^{2}\right)$. The effects are described by the following model:

$$
\begin{aligned}
\operatorname{TSP}\left(\frac{m g}{100 g}\right)= & 45.889-0.273 * P-0.194 * T \\
& -0.058 * E+0.001 * P^{2}+0.029 * T * E
\end{aligned}
$$

$\left(\mathrm{R}^{2}=86.57, \mathrm{p}<0.05\right.$, standard error $\left.=9.20\right)$

Characterization of phenolic compounds. Two chromatograms corresponding to the minimum and maximum experimental factors are shown in Fig. 2. The major phenolic compound identified in all orange peel extracts was hesperidin, with a maximum concentration of $113.03 \pm 0.08 \mathrm{mg} / 100 \mathrm{~g}$. Irkin et al. ${ }^{14}$ emphasized that the high antioxidant capacity of orange peel is associated with its high content of hesperidin.

The maximum concentrations of protocatechuic acid and trans-cinnamic acid were $1.43 \pm 0.05$ and $0.09 \pm 0.00 \mathrm{mg} / 100 \mathrm{~g}$, respectively. Karoui and Marzouk ${ }^{20}$ found higher concentrations of these phenols $(2 \mathrm{mg} / 100 \mathrm{~g})$ for bitter orange peel extracts, but the value of catechin $(4 \mathrm{mg} / 100 \mathrm{~g})$ found by the authors was lower than the maximum determined in the present study $(9.15 \pm 0.25 \mathrm{mg} / 100 \mathrm{~g})$.

The values of ferulic acid $(0.38 \pm 0.00$ to $7.42 \pm 0.13 \mathrm{mg} / 100 \mathrm{~g})$, chlorogenic acid (ND to $0.82 \pm 0.02 \mathrm{mg} / 100 \mathrm{~g}$ ), hesperidin $(14.60 \pm 0.05$ to $113.03 \pm 0.08 \mathrm{mg} / 100 \mathrm{~g})$, p-coumaric acid $(0.06 \pm 0.00$ to $2.07 \pm 0.03 \mathrm{mg} / 100 \mathrm{~g})$, and naringin (ND to $0.35 \pm 0.01 \mathrm{mg} / 100 \mathrm{~g}$ ) were compared with the values obtained for the peel of a hybrid orange citrus (Citrus sinenses $(\mathrm{L}) \times$ Citrus unshiu Marc.) by He et al. ${ }^{21}$, who obtained a ferulic acid concentration of $2.74 \mathrm{mg} / 100 \mathrm{~g}$, chlorogenic acid concentration of $1.39 \mathrm{mg} / 100 \mathrm{~g}$, and hesperidin concentration of $265.75 \mathrm{mg} / 100 \mathrm{~g}$; p-coumaric acid and naringin were not detected.

The concentrations of caffeic acid $(0.02 \pm 0.02$ to $2.11 \pm 0.02 \mathrm{mg} / 100 \mathrm{~g})$, gallic acid $(0.09 \pm 0.00$ to $2.95 \pm 0.01 \mathrm{mg} / 100 \mathrm{~g}$ ), rutin (ND to $2.83 \pm 0.35 \mathrm{mg} / 100 \mathrm{~g}$ ), and quercetin (ND to $0.19 \pm 0.00 \mathrm{mg} / 100 \mathrm{~g}$ ) are in some agreement with the results for orange peel extracts obtained by Irkin et al. ${ }^{14}$, who obtained a caffeic acid concentration of $0.019 \mathrm{mg} / 100 \mathrm{~g}$ and did not detect gallic acid, rutin, and quercetin.

Finally, the values of apigenin (ND to $0.12 \pm 0.00 \mathrm{mg} / 100 \mathrm{~g}$ ) and hesperetin $(0.14 \pm 0.00$ to $1.20 \pm 0.01 \mathrm{mg} / 100 \mathrm{~g})$ differ from those in the study by Menichini et al. ${ }^{22}$ for citrus peel (Citrus medica L. cv Diamante). The main flavonoids found in their study were apigenin $(6.28 \mathrm{mg} / 100 \mathrm{~g})$ and hesperetin $(5.04 \mathrm{mg} / 100 \mathrm{~g})$. 

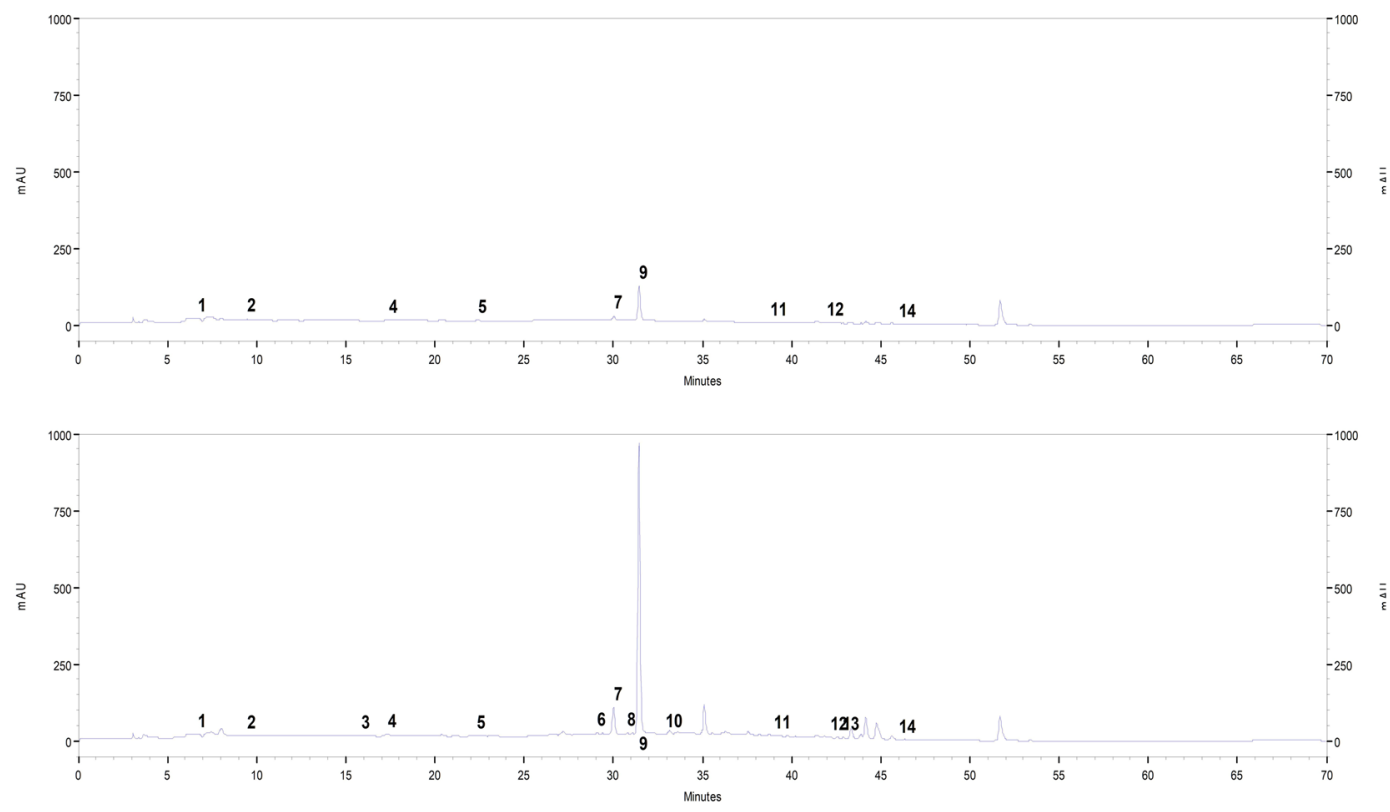

Figure 2. Chromatographic profile for orange peel extracts using UAE for the ultrasonic power, extraction time, and ethanol concentration of $100 \mathrm{~W}, 5 \mathrm{~min}$, and $0 \%$ ethanol (a) and $400 \mathrm{~W}, 30 \mathrm{~min}$, and $50 \%$ ethanol (b). (1) Gallic acid, (2) protocatechuic acid, (3) (+)-catechin, (4) caffeic acid, (5) p-coumaric acid, (6) chlorogenic acid, (7) ferulic acid, (8) naringin, (9) hesperidin, (10) rutin trihydrate, (11) trans-cinnamic acid, (12) quercetin, (13) apigenin, and (14) hesperetin.

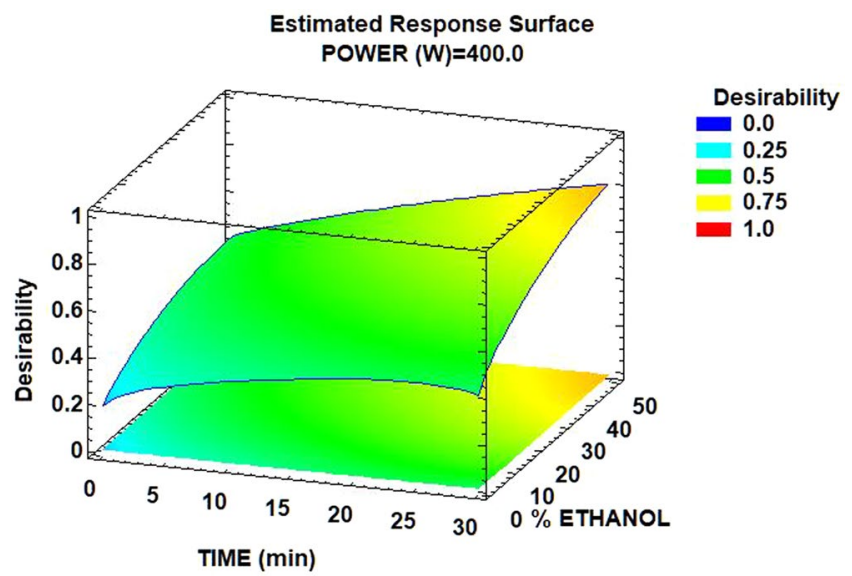

Figure 3. Surface response for the ultrasound-assisted extraction of orange peel compounds.

Optimal extraction conditions. Response surface methodology was used in order to evaluate interactions between experimental conditions, and the desirability function was determined to generate optimum conditions with a desirability value.

The maximum extraction of bioactive compounds from orange peel was achieved with the highest values of the experimental factors. Zou et al. ${ }^{23}$ determined that the optimal percentage of ethanol in water corresponded to $50 \%$ for the extraction of bioactive compounds from Mangifera indica leaves.

The optimal conditions determined using Statgraphics were an ultrasonic power of $400 \mathrm{~W}$, an ultrasound irradiation time of 30 minutes, and a concentration of ethanol in water of $50 \%$. The combination of factors at which the optimum response was achieved generated a desirability value of 0.794 (Fig. 3).

Under optimal conditions, the maximum response values predicted were a carotenoid concentration of $0.52 \mathrm{mg}$ B-carotene $/ 100 \mathrm{~g}$, vitamin C concentration of $63.20 \mathrm{mg} \mathrm{AA} / 100 \mathrm{~g}$, TSP concentration of $94.82 \mathrm{mg}$ GAE/100 g, ORAC of $28.48 \mathrm{mM}$ TE, TEAC of $3.61 \mathrm{mM} \mathrm{TE}$, and $\Delta \mathrm{E}^{*}$ of 26.16 . There was a real efficiency of the assay because the experimental results were consistent with the predictive values. The experiment using $400 \mathrm{~W}, 30 \mathrm{~min}$, and $50 \%$ ethanol resulted in a carotenoid concentration of $0.63 \pm 0.01 \mathrm{mg} ß$-carotene $/ 100 \mathrm{~g}$, vitamin C concentration of $53.78 \pm 3.36 \mathrm{mg} \mathrm{AA} / 100 \mathrm{~g}$, TSP concentration of $105.96 \pm 1.92 \mathrm{mg} \mathrm{GAE} / 100 \mathrm{~g}$, ORAC of $27.08 \pm 2.17 \mathrm{mM}$ TE, TEAC of $3.97 \pm 0.15 \mathrm{mM}$ TE, and $\Delta \mathrm{E}^{*}$ of $28.87 \pm 0.03$. 


\section{Conclusions}

As expected, the optimum extraction conditions of bioactive orange peel compounds using UAE corresponded to the maximum tested values of ultrasonic power, extraction time, and percentage of ethanol in water. It is not studied to increase the percentage of ethanol for the extraction, because our objective was to obtain an extraction with reduced resources (less use of solvents). The established conditions obtained a TC concentration of $0.63 \mathrm{mg}$ ß-carotene $/ 100 \mathrm{~g}$, vitamin C concentration of $53.78 \mathrm{mg} \mathrm{AA} / 100 \mathrm{~g}$, TSP concentration of $105.96 \mathrm{mg}$ GAE/100 g, ORAC of $27.08 \mathrm{mM}$ TE, and TEAC of $3.97 \mathrm{mM}$ TE.

The results of this study suggest that it is possible to use UAE as a non-conventional technique for the extraction of bioactive compounds from orange residues. Moreover, environmentally friendly solvents were used for the extraction without altering the physicochemical parameters of the samples. Finally, response surface methodology was accurate in its determination of the optimum conditions of extraction since the predicted and experimental values were similar.

\section{Methods}

Sample. Navel orange (Citrus sinensis Osb.) was obtained from the Valencian Community. The albedo and flavedo were separated from the edible parts of the fruit, and then the orange peel was cut into squares, each side equal to $0.6 \mathrm{~cm}$, using a regular vegetable chopper (Lacor S.L., España).

Chemicals. $\mathrm{HCl}$ (hydrochloric acid), 2,6-DCFI (2,6-dichloroindophenol), FCR (Folin-Ciocalteu reagent), $\mathrm{K}_{2} \mathrm{~S}_{2} \mathrm{O}_{8}$ (potassium persulfate), ethanol, and gallic acid were purchased from Panreac (Barcelona, Spain). $\mathrm{Na}_{2} \mathrm{HPO}_{4}$ (sodium hydrogen phosphate), $\mathrm{KH}_{2} \mathrm{PO}_{4}$ (potassium dihydrogen phosphate), and $\mathrm{NaHCO}_{3}$ (sodium hydrogen carbonate) were obtained from Scharlab (Barcelona, Spain). $\mathrm{Na}_{2} \mathrm{CO}_{3}$ (sodium carbonate), acetone, acetonitrile, and ascorbic acid were provided by VWR International (Lovaina, Belgium). Formic acid was purchased from Merck (Darmstadt, Germany). Acetic acid, hexane, and methanol were supplied by J.T. Baker (Deventer, The Netherlands). $\mathrm{HPO}_{3}$ (metaphosphoric acid), Trolox ((+/-)-6-hydroxy-2,5,7,8-tetram ethylchromane-2-carboxylic acid), ABTS (2,2'-azino-bis(3-ethylbenzothiazoline-6-sulphonic acid)), AAPH $\left(2,2^{\prime}\right.$-azobis (2-methyl)propionamidine), fluoresceine, protocatechuic acid, $(+)$-catechin, caffeic acid, chlorogenic acid, p-coumaric acid, ferulic acid, trans-cinnamic acid, naringin, hesperetin, hesperidin, and apigenin were obtained from Sigma-Aldrich (St. Louis, USA). Rutin trihydrate and quercetin were obtained from HWI Analytik GmbH (Ruelzheim, Germany). Analytical grade chemicals and distilled water were used.

Extraction procedure. Orange peel squares were placed in a beaker with ethanol-water in a ratio of 1:10 $(\mathrm{g} / \mathrm{mL})^{24}$ as the solvent. The beaker was immersed in ice to prevent the extract from exceeding $40^{\circ} \mathrm{C}$ during ultrasonication; the temperature was controlled by a thermometer Testo 925 (Testo, Germany). The extraction was carried out in the ultrasonic processor Q500 (Qsonica, USA), and the extraction conditions were set as follows: ultrasound power was set to 100,250 , and $400 \mathrm{~W}$; ultrasound irradiation time was 5, 17.5, and $30 \mathrm{~min}$; and the concentration of ethanol in water was $0 \%, 25 \%$, and $50 \%$.

Physicochemical parameters. The physicochemical parameters of orange peel extracts were determined. Two measurements of each sample were taken. The conductivity was measured using an LF330 conductivity meter (Wissenschaftlich-Technische Werkstätten, Germany); $\mathrm{pH}$ and ${ }^{\circ} \mathrm{Bx}$ were measured according to IFU ${ }^{25}$ with MicropH 2001 (Crison, Spain) and Master-T (Atago, Japan), respectively. The color was measured with a ColorQuest XE equipment (HunterLab, USA) considering the CIELAB (Commission Internationale de l'Eclairage $\mathrm{LAB}$ ) system, and non-UAE orange peel extract was used to determine $\Delta \mathrm{E}^{*}$ as the total color difference ${ }^{26}$.

Determination of antioxidant capacity. ORAC (Oxygen radical absorbance capacity) assay. The total antioxidant capacity of the extracts obtained by UAE was evaluated according to the procedure described by $\mathrm{Ou}$ et al. ${ }^{27}$ with the modifications to reagent concentrations made by Zulueta $\mathrm{et} \mathrm{al.} .^{28}$. Fluorescein was added to a white microtiter plate (Sterilin Limited, UK); AAPH, Trolox, and orange peel extracts were added to selected wells to compare the fluorescein degradation. The final reactions were measured using a Wallac 1420 VICTOR2 multilabel counter (Perkin Elmer, USA).

TEAC (Trolox equivalent antioxidant capacity) assay. The TEAC assay shows the capacity of a sample to inhibit the ABTS radical (ABTS• + ) compared with the antioxidant standard Trolox. The method was described by Re et al. ${ }^{29}$ with modifications by Zulueta et al..$^{28}$ for the final reaction tested. The ABTS stock solution was prepared by mixing $25 \mathrm{~mL}$ of ABTS $(7 \mathrm{mM})$ with $440 \mu \mathrm{L}$ of $\mathrm{K}_{2} \mathrm{~S}_{2} \mathrm{O}_{8}(140 \mathrm{mM})$ and incubating the solution in the dark for $16 \mathrm{~h}$ to obtain a stable ABTS working solution for mixing with diluted orange extract (sample/ethanol, 1:25, v/v). The absorbance was measured using a UV/VIS Lambda 2 spectrophotometer (Perkin Elmer, USA) at $\lambda=734 \mathrm{~nm}$ and equilibrated with a Julabo UC-5B circulator thermostat (Julabo, Germany) at $30^{\circ} \mathrm{C}$. Two measurements of each sample were taken.

Determination of bioactive compounds. Ascorbic acid, total carotenoids, total phenolic compounds, and phenolic characterization of orange peel extracts were determined by analyzing duplicate samples.

Ascorbic acid. The ascorbic acid (AA) content in orange peel extracts was determined by redox titration ${ }^{30}$. The ascorbic acid standard was diluted (50\%) with an extraction solution (metaphosphoric acid-acetic acid, 50:50, $\mathrm{v} / \mathrm{v}$ ) and titrated with 2.6 DCFI. The same procedure was used for the samples of orange peel extract. The results are expressed in mg of AA per $100 \mathrm{~g}$ of orange peel. 


\begin{tabular}{|l|l|l|l|}
\hline \multirow{2}{*}{ Run } & $\begin{array}{l}\text { Ultrasound power } \\
\text { W }\end{array}$ & $\begin{array}{l}\text { Time } \\
\text { Min }\end{array}$ & $\begin{array}{l}\text { Ethanol in water } \\
\text { \% }\end{array}$ \\
\cline { 2 - 4 } & $\left(\boldsymbol{X}_{\mathbf{1}}\right)$ & $\left(\boldsymbol{X}_{2}\right)$ & $\left(\boldsymbol{X}_{\mathbf{3}}\right)$ \\
\hline 1 & 400 & 5 & 50 \\
\hline 2 & 400 & 17.5 & 25 \\
\hline 3 & 250 & 17.5 & 0 \\
\hline 4 & 400 & 5 & 0 \\
\hline 5 & 400 & 30 & 0 \\
\hline 6 & 100 & 5 & 0 \\
\hline 7 & 400 & 30 & 50 \\
\hline 8 & 250 & 17.5 & 25 \\
\hline 9 & 100 & 17.5 & 25 \\
\hline 10 & 100 & 30 & 50 \\
\hline 11 & 100 & 5 & 50 \\
\hline 12 & 250 & 17.5 & 25 \\
\hline 13 & 250 & 17.5 & 50 \\
\hline 14 & 100 & 30 & 0 \\
\hline 15 & 250 & 30 & 25 \\
\hline 16 & 250 & 5 & 25 \\
\hline
\end{tabular}

Table 1. Experimental design matrix of CCD in terms of variables for experiments on UAE for orange peel.

Total carotenoids. The total carotenoids (TC) in the samples were determined using the spectrophotometric method by Lee and Castle ${ }^{31}$. Orange peel extract $(2 \mathrm{~mL})$ with extracting solvent (hexane/acetone/ethanol, 50:25:25, v/v) $(5 \mathrm{~mL})$ was centrifuged for $5 \mathrm{~min}$ at $4000 \mathrm{rpm}$ and $5^{\circ} \mathrm{C}$ in a $5810 \mathrm{R}$ centrifuge (Eppendorf, Germany). The supernatant was diluted (1:1, v/v) with hexane, and the absorbance was measured at $450 \mathrm{~nm}$ on a UV/VIS Lambda 2 spectrophotometer (Perkin Elmer, USA). For determining the concentration of total carotenoids, the extinction coefficient of $\beta$-carotene $E^{1 \%}=2505$ was used in accordance with Ritter and Purcell ${ }^{32}$. The results are expressed in $\mathrm{mg}$ of $ß$-carotene per $100 \mathrm{~g}$ of orange peel.

Total soluble phenols. Total soluble phenols (TSP) were determined according to the colorimetric method of Singleton and $\operatorname{Rosi}^{33}$ with the modifications of George et al. ${ }^{34}$. For the standard curve, $0.1 \mathrm{~mL}$ of gallic acid calibration standard with concentrations of $0-1000 \mathrm{ppm}$ were placed in tubes with $0.1 \mathrm{~mL}$ of Folin-Ciocalteau reagent $(1: 1, \mathrm{v} / \mathrm{v})$ and $3 \mathrm{~mL}$ of sodium carbonate solution $(2 \%, \mathrm{w} / \mathrm{v})$ and incubated for $60 \mathrm{~min}$ at room temperature in darkness. The same procedure was used for orange peel extracts diluted with distilled water $(1: 1, \mathrm{v} / \mathrm{v})$. TSP determination was carried out by measuring the absorbance at $\lambda=765 \mathrm{~nm}$. The results are expressed in mg of gallic acid equivalents (GAE) per $100 \mathrm{~g}$ of sample.

Characterization of phenolic compounds. A quantitative analysis of phenolic compounds was performed by using high-performance liquid chromatography (HPLC) in accordance with Cichova et al..$^{35}$. The analytical system used was an Agilent 1120 Compact LC (Agilent Technologies, Germany) with a UV $280 \mathrm{~nm}$ detector and equipped with a $4.6 \times 250 \mathrm{~mm}$ column Luna C18, $100 \AA$, $5 \mu \mathrm{m}$ (Phenomenex, USA). The flow rate was $1 \mathrm{~mL} / \mathrm{min}$, the temperature of the column oven was $25^{\circ} \mathrm{C}$, and the injection volume was $20 \mu \mathrm{L}$. The mobile phase consisted of water-formic acid $(95: 5, \mathrm{v} / \mathrm{v})$ as solvent $\mathrm{A}$ and acetonitrile-solvent $\mathrm{A}(60: 40, \mathrm{v} / \mathrm{v})$ as solvent B. A gradient program was carried out as follows: $0 \mathrm{~min}, 100 \% \mathrm{~A} ; 10 \mathrm{~min}, 85 \% \mathrm{~A} ; 20 \mathrm{~min}, 82 \% \mathrm{~A} ; 50 \mathrm{~min}, 0 \% \mathrm{~A}$; $65 \mathrm{~min}, 100 \% \mathrm{~A} ; 70 \mathrm{~min}, 100 \% \mathrm{~A}$.

The analytical standards were prepared at a stock concentration of $200 \mu \mathrm{g} / \mathrm{mL}$. The preparation of the sample before running the HPLC auto-sampler consisted of injecting $5 \mathrm{~mL}$ of methanol and $10 \mathrm{~mL}$ of water in a Sep-Pak C18 cartridge (Phenomenex, USA); then, $5 \mathrm{~mL}$ of orange peel extract, adjusted to $\mathrm{pH} 1.6$, was passed through the cartridge. Phenolic compounds were collected with $12 \mathrm{~mL}$ of acetone, which was then evaporated with nitrogen and dissolved with $1 \mathrm{~mL}$ of $\mathrm{HCl} 0.6 \mathrm{M}$ /aqueous methanol $75 \%$. The results are expressed in $\mathrm{mg}$ per $100 \mathrm{~g}$ of orange peel.

Experimental design and statistical analysis. A central composite design (CCD) was used to evaluate the effects of independent variables (ultrasound power: 100, 250, and $400 \mathrm{~W}$; ultrasound irradiation time: 5, 17.5, and $30 \mathrm{~min}$; and concentration of ethanol in water: $0 \%, 25 \%$, and $50 \%$ ) on the dependent variables (color, antioxidant capacity, ascorbic acid, carotenoids, and TSP). The selection criteria for the levels of experimental factors levels included the operating conditions of the UAE equipment and the characteristics of the sample.

CCD is an experimental design used to obtain the maximum information in a study from a minimal number of experiments. Further, CCD is a suitable standard design that can be used in response surface methodology (RSM) because of its high efficiency and the number of runs required. The type of CCD used was the central composite face-centered (CCF) design, in which the start points are placed at the center of each face of the factorial space $(\alpha= \pm 1)$. CCF was performed with the combinations shown in Table 1 at three levels (maximum, central, and minimum: $+1,0,-1)$ of each independent variable. 
During execution, the experiments were randomized to increase accuracy and minimize systematic bias. Once the different treatments of samples were carried out in duplicate, the optimal settings of the experimental quantitative factors were identified. Analysis of variance (ANOVA) was performed in order to test the statistical significance $(\mathrm{p}<0.05)$ of the effects by comparing the mean square with an estimate of the experimental error. In this way, the test helped to find the best design points to obtain a combination of the low and high levels of each factor with the highest predicted desirability.

RSM was applied to determine the optimal conditions of the significant factors of extraction and to obtain a predictive model that describes changes in the response depending on ultrasound power, ultrasound irradiation time, and the concentration of ethanol in water. RSM involves the simultaneous effects of the three levels of each experimental factor and establishes a response variable as a linear function of experimental factors, interactions of factors, error, and quadratic effects.

The desirability function was used on a scale of 0 to 1 to determine the combination of levels of independent variables that maximize the desirability of values of the dependent variables.

The experimental design generation and statistical methods were performed using the software Statgraphics Centurion XVI 15.2.06 (Statpoint Technologies Inc., USA).

\section{Data availability}

The datasets generated during and/or analysed during the current study are available from the corresponding author on reasonable request.

Received: 13 February 2019; Accepted: 22 October 2019;

Published online: 06 November 2019

\section{References}

1. Slow Food International. Slow food about us, http://www.slowfood.com/about-us/ (2015).

2. Del Pozo, S. et al. Valoración nutricional de la dieta española de acuerdo al panel de consumo alimentario (Fundación Española de Nutrición, 2012).

3. Prakash, D. \& Kumar, N. Cost effective natural antioxidants in Nutrients, dietary supplements, and nutriceuticals (eds Gerald, J. K., Watson, R., \& Preedy, V. R.) 163-187 (Humana Press, 2011).

4. Mercabarna \& AGEM, Mercabarna y la Associació Gremial d'Empresaris Majoristes de Fruites i Hortalisses de Barcelona i Província. Naranja citrus sinensis, http://www.5aldia.es/es/az_fitxa.php?id=133\&letra=N (2015).

5. Baldwin, E., Bai, J., Plotto, A. \& Ritenour, M. Citrus fruit quality assessment; producer and consumer perspectives. Stewart Postharvest Rev. 10,1-7 (2014).

6. FAO. Crops, http://www.fao.org/faostat/en/data/QC (2015).

7. USDA. U.S. food waste challenge, http://www.usda.gov/oce/foodwaste/faqs.htm (2015).

8. BSR. Analysis of U.S. food waste among, food manufacturers, retailers, and wholesalers, http://www.foodwastealliance.org/wpcontent/uploads/2013/06/FWRA_BSR_Tier2_FINAL.pdf(2013).

9. EEA. Food waste, https://www.eea.europa.eu/signals/signals-2012/close-ups/food-waste (2012).

10. Park, J. H., Lee, M. \& Park, E. Antioxidant activity of orange flesh and peel extracted with various solvents. Prev. Nutr. Food Sci. 19, 291-298 (2014).

11. Kour, R., Rastogi, A., Sharma, R., Kumar, A. \& Raghuwanshi, P. Chemical composition, anti-oxidative activity and in vitro dry matter degradability of Kinnow mandarin fruit waste. Vet. World 7, 803-806 (2014).

12. Londoño-Londoño, J. Use of waste from the citrus agro industry: extraction and characterization of flavonoids in Perspectivas $y$ avances de investigación de la serie lasallista 395-416 (Corporación Universitaria Lasallista, 2011).

13. Khan, M. K., Abert-Vian, M., Fabiano-Tixier, A.-S., Dangles, O. \& Chemat, F. Ultrasound-assisted extraction of polyphenols (flavanone glycosides) from orange (Citrus sinensis L.) peel. Food Chem. 119, 851-858 (2010).

14. Irkin, R., Doğan, S., Değirmencioğlu, N., Diken, M. \& Guldas, M. Phenolic content, antioxidant activities and stimulatory roles of citrus fruits on some lactic acid bacteria. Arch. Biol. Sci. 67, 1313-1321 (2015).

15. Legua, P., Forner, J. B., Hernández, F. \& Forner-Giner, M. A. Total phenolics, organic acids, sugars and antioxidant activity of mandarin (Citrus clementina Hort. ex Tan.): variation from rootstock. Sci. Hortic. 174, 60-64 (2014).

16. Alvarez, J., Pastoriza, S., Alonso-Olalla, R., Delgado-Andrade, C. \& Rufian-Henares, J. A. Nutritional and physicochemical characteristic of commercial Spanish citrus juices. Food Chem. 164, 396-405 (2014).

17. M'hiri, N., Ioannou, I., Boudhrioua, N. M. \& Ghoul, M. Effect of different operating conditions on the extraction of phenolic compounds in orange peel. Food Bioprod. Process. 96, 161-170 (2015).

18. Cano, A. \& Bermejo, A. Influence of rootstock and cultivar on bioactive compounds in citrus peels. J. Sci. Food Agric. 91, 1702-1711 (2011).

19. Fidrianny, I., Harnovi, M. \& Insanu, M. Evaluation of antioxidant activities from various extracts of sweet orange peels using DPPH, FRAP assays and correlation with phenolic, flavonoid, carotenoid content. Asian J. Pharm. Clin. Res. 7, 186-190 (2014).

20. Karoui, I. J. \& Marzouk, B. Characterization of bioactive compounds in Tunisian bitter orange (Citrus aurantium L.) peel and juice and determination of their antioxidant activities. Biomed. Res. Int. 2013, 345415 (2013).

21. He, D. et al. Simultaneous determination of flavanones, hydroxycinnamic acids and alkaloids in citrus fruits by HPLC-DAD-ESI/ MS. Food Chem. 127, 880-885 (2011).

22. Menichini, F. et al. Citrus medica L. cv Diamante (Rutaceae) peel extract improves glycaemic status of Zucker diabetic fatty (ZDF) rats and protects against oxidative stress. J. Enzyme Inhib. Med. Chem. 31, 1270-1276 (2016).

23. Zou, T. B. et al. Ultrasound-assisted extraction of Mangiferin from Mango (Mangifera indica L.) leaves using response surface methodology. Molecules 19, 1411-1421 (2014).

24. Moulehi, I., Bourgou, S., Ourghemmi, I. \& Tounsi, M. S. Variety and ripening impact on phenolic composition and antioxidant activity of mandarin (Citrus reticulate Blanco) and bitter orange (Citrus aurantium L.) seeds extracts. Ind. Crops Products 39, 74-80 (2012).

25. IFU. Methods of analysis. Loose-leaf collection (Swiss Fruit Associations, 2001).

26. Calvo, C. Optical properties in Handbook of food analysis physical characterization and nutrient analysis (ed. Nollet, M. L.) 1-19 (Marcel Dekker Inc., 2004).

27. Ou, B., Hampsch-Woodill, M. \& Prior, R. L. Development and validation of an improved oxygen radical absorbance capacity assay using fluorescein as the fluorescent probe. J. Agric. Food Chem. 49, 4619-4626 (2001).

28. Zulueta, A., Esteve, M. J. \& Frígola, A. ORAC and TEAC assays comparison to measure the antioxidant capacity of food products. Food Chem. 114, 310-316 (2009). 
29. Re, R. et al. Antioxidant activity applying an improved ABTS radical cation decolorization assay. Free Radic. Biol. Med. 26, 1231-1237 (1999).

30. AOAC. Official methods of analysis (AOAC International, 2000).

31. Lee, H. S. \& Castle, W. S. Seasonal changes of carotenoid pigments and color in Hamlin, Earlygold, and budd blood orange juices. J. Agric. Food Chem. 49, 877-882 (2001).

32. Ritter, E. \& Purcell, A. Carotenoid analytical methods in Carotenoids as colorants and vitamin A precursors (ed. Bauernfeind, J.) 815-923 (Academic Press, 1981).

33. Singleton, V. L. \& Rossi, J. A. Colorimetry of total phenolics with phosphomolybdic-phosphotungstic acid reagents. Am. J. Enol. Vitic. 16, 144-158 (1965).

34. George, S., Brat, P., Alter, P. \& Amiot, M. J. Rapid determination of polyphenols and vitamin C in plant-derived products. J. Agric. Food Chem. 53, 1370-1373 (2005).

35. Cíchová, M., Petř́ícek, J. \& Fiala, J. Influence of Tannin addition on the content and composition of polyphenolic compounds in wines. Czech J. Food Sci. 26, S33-S38 (2008).

\section{Acknowledgements}

This work was supported by Conselleria d'Educació Cultura I Esport - Generalitat Valenciana, Spain [AICO2015-083].

\section{Author contributions}

M.J.E. and A.F. jointly conceived the study. A.M.C. analyzed the data. A.Z. and C.C. prepared the manuscript. All authors interpreted the results, edited the manuscript, and approved the final version to be published.

\section{Competing interests}

The authors declare no competing interests.

\section{Additional information}

Correspondence and requests for materials should be addressed to M.J.E.

Reprints and permissions information is available at www.nature.com/reprints.

Publisher's note Springer Nature remains neutral with regard to jurisdictional claims in published maps and institutional affiliations.

(c) (i) Open Access This article is licensed under a Creative Commons Attribution 4.0 International License, which permits use, sharing, adaptation, distribution and reproduction in any medium or format, as long as you give appropriate credit to the original author(s) and the source, provide a link to the Creative Commons license, and indicate if changes were made. The images or other third party material in this article are included in the article's Creative Commons license, unless indicated otherwise in a credit line to the material. If material is not included in the article's Creative Commons license and your intended use is not permitted by statutory regulation or exceeds the permitted use, you will need to obtain permission directly from the copyright holder. To view a copy of this license, visit http://creativecommons.org/licenses/by/4.0/.

(C) The Author(s) 2019 